\title{
HistoricAl REPORT AS NARRATIVE PROCEDURE
}

\author{
Juremir Machado da Silva
}

\begin{abstract}
This text approaches the intersection of history, journalism and literature as a procedure for the constitution of a specific narrative, the great historical or intellectual report of deepening. A simple question is explored: what if the historian is a journalist who covers the past and narrates him as a writer?
\end{abstract}

KeYwORDS

Literature; history; journalism; narrative

\section{REPORTAGEM HISTÓRICA COMO PROCEDIMENTO NARRATIVO}

\begin{abstract}
RESUMo
Este texto aborda o cruzamento de história, jornalismo e literatura como procedimento para a constituição de uma narrativa específica, a grande reportagem histórica ou intelectual de aprofundamento. Explora-se uma questão simples: e se o historiador for um jornalista que cobre o passado e o narra como um escritor?
\end{abstract}

\section{Writer, JournaLIST, Historian}

When everything is narrative, the highest expression of an unavoidable relativity, it is a matter of deciding how to narrate. This choice draws what will be narrated out of its condition of amorphous mass of data. An always decisive aspect is the point of view as the place where one speaks from: view of a point. But it can also be simply who speaks. This subject of the discourse is per se a privileged place of speech. An author can transfer this position of enunciation to a character; or place oneself as the speaker. What place of speech should be chosen to narrate the life of a historical character: an external point of view or an internal one, from inside his/her head? How should one narrate the moment when Getúlio Vargas decided to pull the trigger of his small gun at 8:35 a.m. on August $24^{\text {th }}, 1954$ ?

Is it possible to produce a narrative specificity by intersecting, in the same authorial procedure, techniques of a writer with his/her background as historian and his/her imagination as a journalist? In a conceptual rapture, it would be possible to sustain that 
biographies, nonfiction novels, anthropologic ethnographies, field researches of all kinds and historical descriptions are always great reports. All of them based on the same principles: to raise data, date back to periods and individuals, or observe events and recover all the sides involved. In any case, under any pretext, it is about trying to uncover what is covered up, give rise to what is hidden, bring to light, unveil, reveal, clarify, focus, disclose, enlighten.

Each field of knowledge, evidently, builds fences to protect its domains and preserve its hard-won properties. Pierre Bourdieu (1998, pp. 40-41) openly reveals his realism:

a field is a structured social space, a field of forces, a force field. It contains people who dominate and others who are dominated. Constant, permanent relationships of inequality operate inside this space, which at the same time becomes a space in which the various actors struggle for the transformation or preservation of the field. All the individuals in this universe bring to the competition all the (relative) power at their disposal. It is this power that defines their position in the field and, as a result, their strategies.

This definition is frequently object of dissection. It is important to note that it highlights the conflict, the self-interests involved, the closing, the correlation of forces, and the rationality of the strategies adopted. It is implied that there is mobility in the field. Why defining strategies if there is no chance of victory? The dominant may become dominated, which may become dominant. The heresy becomes canon. The canonic suffers the corrosion of the time and the new. Each period, however, produces its conditions of canonization and its representatives. The literary field (Bourdieu, 1992) is not different. It gives prizes, trophies, medals, certificates and awards. It legitimizes and delegitimizes works and authors according to the aimed subjectivity of the "owners" of the area in given period. Intersecting literature, history and journalism means coming into conflict with the dominants of three different fields. It may be a good narrative strategy, but it is not revealed at first sight as a reasonable legitimation strategy.

A pragmatic view on legitimation in the literary field indicates that there are two main ways: the acceptance by the critique or the acceptance by the readers. It is about selling little, but being admired by "opinion makers", or selling a lot and placing oneself as an author of market. The crossing of both is infrequent. Paulo Coelho is the most famous example of the second case. As a best-seller, he keeps being rejected by the journalistic and academic criticism. The field controllers cannot prove they are right, since there is not "right" anymore concerning taste and cultural consumption. But they keep holding an envied power, including by Paulo Coelho, the power of legitimation. Publishing books does not make a writer; it makes, at most, an author. The acknowledgment works as a certification. Each field is a registry office able to issue a birth certificate to whoever shows up. Death certificates are also issued. The worst, however, seems to be the indifference, the non-certification by refusing to receive the case.

Why is there such necessity of certification in a period of crisis of references and parameters in which all the tastes are equally legitimate? This may be the great paradox of 
the present time: when everything is possible, without absolute hierarchies, only the acknowledgment expressed by an "authority" known by the plaintiff of legitimation seems to be able to establish a safe value. Guy Debord (1995, p. 15) sustained that all the spectacle says is "what appears is good; what is good appears". It is a circular validation criterion. The good thing is the one that works. If it works, it is good. How does it work? If it has readers, it is good. If it is good, it has readers. The rest is bad - unless the one that finds a favorable critique, a frequently minimum level of reading and sales, being good for this court of reputations and for the author's vanity, and even for his/her career insofar as prizes can be awarded.

Jean-François Lyotard (1984, p. 16), one of the greatest theorists of postmodernity, as a privileged space of distrust regarding "legitimating narratives", highlighted another relevant aspect:

in a society whose communication component is becoming more prominent day by day, both as a reality and as an issue, it is clear that language assumes a new importance. It would be superficial to reduce its significance to the traditional alternative between manipulatory speech and the unilateral transmission of messages on the one hand, and free expression and dialogue on the other.

What may be the meaning of this aspect of language in the strategies of legitimation in a given field? In a more immediate perspective, it may be a "stunt", as an argumentative or visibility strategy, a marketing ploy, a mean to scale the field's hierarchy thanks to valuation devices, going from inexistent to dominated and from dominated to dominant. In a more dialogic perspective, however, the situation is nobler: the person who writes usually does that to be read. It means that he/she gets into an intersubjective position, wants to be acknowledged and needs - if this is not a practitioner of some aesthetic solipsism - this external acceptance to exist and make this work worth it. And here another paradox possibly comes up: to be acknowledged in a given field, is it strategically better to follow one's own rules or to challenge them? Must one write for the field or for oneself? Can writing for oneself be the most efficient strategy to be acknowledged by others?

Evidently, this topic is not new. But it can be explored by different angles; or drawn out from its invisibility. The artist must produce the evaluations standards of his/her work. The price to be paid is the rejection of its field. The consolation received is at considering oneself as misunderstood. The history of literature is abundant in encouraging examples for those who have not reached the desired legitimation. In case of despair, it is always possible to mention Marcel Proust's case, who had his masterpiece refused by André Gide at Éditions Gallimard. The issue addressed here, however, goes beyond sadness and resentment of the ones who have not been awarded by their peers or readers: how to dare in terms of narrative when it is dependable on acknowledgment of a field, or several fields, with its rules and controllers? A generous possibility is to establish the production of novelty and originality as a golden rule in the artistic field. In other words, it would mean production of difference and discovery (Silva, 2017) as a rule. 


\section{THE NARRATIVE AS A STAKE}

The question that remains is: what can be considered novelty, originality, difference and discovery? The difference, as radical novelty, can be justly the discovery: make something emerge, disclose, reveal, unveil, bring it up. A literature of discovery may be the one that produces difference, then originality, uncovering through report techniques what was covered up by history, and it requires transdisciplinary view and narrative in order to be seen in the fullness of its mysteries.

It is also a matter of method. Paul Feyerabend (1993, p. 106), an advocate of "libertarian epistemology", provokes:

a prevalent tendency in philosophical discussions is to approach problems of knowledge sub specie aeternitatis, as it were. Statements are compared with each other without regard to their history and without considering that they might belong to different historical strata. For example, one asks: given background knowledge, initial conditions, basic principles, accepted observations - what conclusions can we draw about a newly suggested hypothesis?

Which conclusions can be made after a proposal of intersecting history, journalism and literature whose aim is to collect data and narrate the past as a great report without representing a simplification of the historian's procedures nor "romanticizing" a supposed historical truth, but, on the contrary, a complexification? Given the initial conditions, exposed in tone of provocation, it is possible to consider that a historian, a journalist and a writer can assume the position of reporter covering the past. It is a matter of technique and competence, or even - slippery category - "talent". Overall, evidently, it is about transdisciplinary attitude.

Edgar Morin (1999, p. 164) sees in the transdisciplinary attitude a complex relation between explanation and comprehension:

the explanation is an abstract process of demonstrations logically made, from objective data, due to material or formal causal needs and/or due to an adaptation to structures or models. The comprehension moves specially along concrete, analogical, intuitional, subjective spheres. The explanation moves specially along abstract, logical, analytical, objective spheres. The comprehension comprehends due to projective/identifiable transferences. The explanation explains due to logical-empirical pertinence of its demonstrations, while comprehending means to capture the existential meanings of a situation or phenomenon.

Why not to suppose that there is only advantage in covering and narrating the past allied with the sensibilities and techniques of journalists, historians and writers who, in a joint movement, or even all of them in only one researcher/author, deeply and complexly, are able to make a bridge between explanation and comprehension, abstraction and empathy, interpretation and description, reconstruction and verification? 
Paul Veyne (1998, pp. 89-90), author of a classic about the traps of historical narrative, warned, with good sense and elegance, the ones who would not fear accepting his statement:

since such is the quintessence of historical explanation, it must be agreed that it does not deserve so much praise and that it is hardly distinguishable from the kind of explanation in use in everyday life or in any novel in which that life is related. It is but the light emanating from a sufficiently documented account; it offers itself to the historian in the narrative and it is not an operation separate from the latter, any more than it is for a novelist.

Nothing can be invented in history and in journalism. Not everything, however, can be proved, demonstrated, solved, elucidated, explained, found out, discovered, showed. The documents tell their truth, but they do not tell how they were produced. Each narrative choice cuts out the object that will be described, lighting up a part of it and leaving others in the shadows. The historian and the journalist interfere in the fact that will be narrated simply because they use observation "lenses". There is no neutral look. They select what to tell, what to highlight, which perspective to adopt, choose the proper moment to go from explanation to comprehension and vice versa, fill out gaps by deduction, interact with their data and research peers aiming a credible and convincing narrative. An archeologist, for example, produces narratives that require even intuition and imagination. The great historian, then, can be a reporter who covers the past with the sensibility of a writer and the techniques of these three areas associated in an attitude that brings down the fences of these fields.

\section{THE TIME OF WRITING}

The act of thinking about what to write compels the author to look back to what he/she is used to write. Each author has obsessive themes. What is the time of writing? Modernity? Post-modernity? If it is the post-modernity, how should the author focus on it? Some possibilities: a) the crisis of the idea of truth in human sciences and arts, or the crisis of legitimizing narratives; b) the end of the illusion of emancipation for the absolute reason; c) the end of the idea of a man as a subject that is rational, conscious and nature-dominator in an inexorable journey towards the goodness, the beautifulness and the truth; d) the decline of the redeeming utopias and the myth of progress; e) the end of the illuminating and illuminist vanguards; f) ironic nihilism; g) cynical humor; $h$ ) radical skepticism; i) epistemological and esthetical relativism; j) merging of genres in arts; k) deconstruction; I) parody; $m$ ) pastiche; $n$ ) return to the narrative without recovering the 19th-century realism nor the assimilation by the "storyteller", simplifier of the cultural industry; o) the end of the idea of representation; $p$ ) the end of the separation between high and low culture; q) the rupture with the structuralism (post-modernity would be post-structuralist, but post-structuralism would not always be post-modern, being, several times, a new form of militancy or the North-American view of French 
post-modernity); r)the return of subjectivity (for example, in the literary text in opposition to the objectivism of the new novel), equivalence between signifier and signified; s) the return of the clean sentence, in literature, in opposition to the modern language experimentalism based on the word implosion or explosion; t) intertextuality, collage, quotation, merging, saturation of images, baroque, crossing of stiles and times, eclecticism; u) high-voltage narrative concentration by discursive acceleration, simulation of "I" as bearer of a pseudouniversal; v) extreme colloquialism and self-irony; w) ironical recovery of fiction of ideas without thesis defense nor militantism; $x$ ) epistemological and esthetical anarchism; y) approach of culture and ideology as imaginary or as simulation of reality, that is, as hyper-reality, surreality, unreality; z) after truth.

Each item of this alphabet would require some demonstration. The question, however, is another one, about contextualization. What does the time show? What does a narrative bear from its time? What does a movie, for example, say behind the scenes? What does a book tell beyond what is written? What does a work reveal about what it does not say explicitly? What does irony unmask? Let us take a case. What does this text say? The algorithms already dominate the world. Their spokespersons assure they are good-natured. Would not they say this while manipulated by their master algorithms? These algorithms, like psychopaths, can be very intelligent. It is an opaque intelligence. With no return. Soon, we will all be slaves of algorithms. Since we will not have social utility anymore, we will serve exclusively to satisfy the perversity of the algorithms.

A first hypothesis: reveals the fear regarding the technological advance. A second possibility: relativizes the force of technique by emphasizing a step back of subjectivity. If the imaginary reveals meanings that the conventions of a time may block, what does a piece of work say - movie, book, chronicle, lyrics, biography - about a time whose coverage has not ended up yet? The interpreter does not link him/herself to what is lived as a blank screen. The lens and the screen meet in a relation that can be freely triggered. Methodological hypothesis: what if the imaginary is the result of the lens that triggers the screen with its degree and is teased by what it sees generating a new profusion of images? What if the imaginary is the mechanism that leads the hand to choose what to write? What if the imaginary is a secret agent of its time?

The viewer and the reader do not have guarantees against what they watch or read. But what do they watch or read? The meaning of the reception may be altered if the viewer or reader finds an atmosphere of adhesion or rupture. This condition tends to come up with the erosion of the instituted, frozen image of the emission as a propose of viewing, which never ceases to be recomposed in permanence by the restorative action of reception. The image offered as photography or narrative is a conditioning procedure that operates as a perfume whose smell disperses by reaching the receptor. The imaginary, as a circuit that goes from the image captured or built to the deconstruction or construction of a narrative, is a social perception of the one who sees on what is projected to be seen, the work as reconstruction of what was lived, a recalling, or its simulation, mediated by the sequence of images and turned by who feels, the one who, by felling, gives meaning, which only exists as a report of an interpretation that was lived. 
If the book and the movie allow a reconstruction of what was lived, the meaning attributed inquires the image forcing it to say what it shows. This banal sequence requires a discourse. What is this discourse? What do the captions say? For, in a sense, it is all about this: caption an image, comment the text, reveal the subtext, dialogue with what is covered. For that, it is necessary to review the set of images as a structured whole that presents itself as something else than the sum of the parts. This journey from the end to the beginning stablishes a trajectory through which the interpreter interprets him/ herself. In the interpretation, it is possible to find the captured view and the action of capturing. This relation of reading may be a conscious or unconscious operation of clarification, even if the imaginary of the cinema or book feeds itself from the atmosphere of the darkness. Everything can be clearer in the darkness interrupted by the floodlight of the screen or by the transparence of the page covered by signs. The interpretation as a method of reconstruction forces to say what was seen and read, which can be brought to light only the day after, at the end of the reception. The word "projection", regarding movies, may say even more: exhibition of the project, orientation of viewing, delivery of the proposal. Every film provides lens for the viewer to comprehend it. Every book suggests its reading. The viewer and the reader, however, have in their pocket their own lens, which turns them into interpreters, who watch and retrace the narrative while reading.

What unfreezes the image, as interpretative act or reconstruction of a project, is the key for interpreting the course. In the journey from the image to the imaginary, a structure is built, which is subject to decoupage. The one that makes the decoupage reads, decompose, recompose, reinvents, narrates and proposes. The spectator - every reader is a spectator -, converted into interpreter, gets free from the project of the author and projects him/herself in the work as a usurper, a betrayer, an assembler, a screenwriter, a narrator, an author. The interpretation dismantles and reconfigures. Every interpretation is an act of assumed and necessary infidelity. The interpreter, this reader that views and reviews, impacts the narrative foundation.

What is seen through images that evoke the world of the songs? What is seen through signs that retrace an absent universe? The imaginary can be listened, seen and read as a song. The note that overflows and echoes such a soundtrack that supports what was lived, the musicality that was in the course as projection of the being. The work of decoupage (reconfiguration reading) of the imaginary is never free of this vibration that explores the sonority of the metaphor as image in image. Interpreting is to make vibrate the silenced meanings, offer the hearing, lighten, dialogue with the image, explore what is underlying, tease what is exceeding, review or choose the captions, provoke image with text until the production of a context, an aggregate of images over images. The one who interprets imagines, reveals, unveils, exhibits to him/herself and to the one who will interpret him/herself, says what was seen from the point of view of the reflection, which is always distorted. Viewing and reading is setting oneself under the light of comprehension. It is disrobing by the screen.

The interpretations is a process of successive and permanent approximations. The first glance is exploratory and dilettante. It may be ingenuous or cautious, informed or 
conformed. It faces the plowed soil, signed by the author's plow, recovered by the symbolic forest of what was narrated. Interpreting is not collecting the mature image, but looking for roots of what was inseminated. The one who interprets and what is interpreted discover themselves simultaneously. The interpreter suggests a narrative for the interpreted. This suggestion is neither true nor false. It is an unveiling, an encounter of perspectives, a dialogue in act. This teasing projects evocations that tease new cognitive operations. Interpreting moves the images out of inertia.

The interpretation of the imaginary may require a surface hermeneutics, since the layer that covers the image, before its transfiguration into imaginary, remains within arm's reach. Interpreting is to remove this tenuous layer. Digging and dusting, watching, listening and telling, feeling, vibrating and narrating. The interpretation that gains adhesion legitimates itself as pertinent reading. During the interpretation, there is always some loss, the loss of this original discourse, which originates from the authoring.

The interpreter invades the stage, gets into the screen, the page, plays a role, takes over the setting, reorganizes the scene, narrates what is watching and inquires the event as a new actor, narrator and author. But the interpreter does not act freely such as in authorial fiction. The interpretation follows a script, even if it serves only for being questioned or denied. The reference is there to be peeked. The dialogic act of interpretation cannot prescind from the encounter of parts. It is like if, at each defining moment, it were necessary to look back to check an image, a paragraph, a symbol, an effect, precisely a mark, the consummate reference.

The interpretation is comprehensive and relativist. It puts empathy in relation and practices it. It explores the impossibility of reducing the image to closed reason. The abstract procedures of logics have low power in the face of the experience that guides the viewing. The comprehension does not escape from the fascination. The interpretation dialogues with the explanations and the comprehension in open plan, free page, text in progress. The post-modernity has put under suspect old truths that were considered universal ones without the evidence of the evidence of this disproportionate ambition. It showed how much fiction and construction there is in each report. Paradoxically, at this time of distrust about the reality of what is real, readers have appreciated, like never before, "real" narratives: testimonies, travel reports and biographies. The author needs to convince the reader that he/she had been there. Narrating is living.

Every definition is taken as a narrative and, as such, open to irony and relativization. Some examples may be cited for teasing. Ideology: lens that defines what is observed; glasses that conform, deform or reform the narrative, being able to coincide with what was described. Social imaginary: collective fiction shared as objective reality. Politics: domestication of power or power of domestication. Political science: each one's opinion on the academy rules. Economy: science with a power of foresight as efficient as the astrology's. Impeachment: the coup in the beneficiary's point of view. Coup: the impeachment that did not convince everyone. Democracy: political system in which each vote may be priced before or after the election. Reality: autofiction sustained by people with high self-esteem. 
Other possibilities. Law: ideology through which certain people can say what is the law. Communism: the worst form of socioeconomic organization with the capitalism. Media: system for manipulation of opinion so that it becomes public. Public opinion: worldview from private origin, whose author is unknown and consequences are predictable. Professional politician: person that gave up a profession in order to live as an amateur. Marketing professional: expert in deforming the reality preferably without lying, but also not saying the truth. Youtubers: famous people that the majority still does not know. Artificial intelligence: machines' natural wisdom. Bestseller: book read by who never opens a book. Post-work: name that will be given to a world where everyone will be unemployed. Post-human: evolution of the man for his absolute animal condition.

In times of general acceptance of the fact that the sciences, not only the human ones, but especially them, are probabilistic, working with the hypothesis that they always have to be exposed to successive refutations, every report, or even every research report, is narrative, which erases the supposed clearness of the boundary with the essay. In this sense, everything is experimentation, possibility or stake.

\section{Provisional CONClusion}

The focus of this text was not the lack of legitimation of those who, by any chance, put in practice the complex intersection between journalism, history and literature. This was only a secondary or derived issue. The main point of this reflection was centered on the idea of thinking the historian as a reporter who covers the past recurring to narrative tools of a writer in order to disseminate results. In other words, recovering a polysemic term, the historian is a chronicler that interprets the past. The term chronicler, however, gained day by day a literary meaning, the literature in journalism. The chronicle deeply explores the comprehension, the empathy, the description, the narration, the reconstruction.

From a practical point of view, what can a chronicler/reporter of the past dare in the presentation of a material, without losing accuracy, giving to it a readable form in other fields, where, several times, it is not even read, serving only as a report to prove the work was done? Can he/she eliminate the field jargon? Can he/she be clear without taking the risk of being accused of superficiality? Can he/she give more value to empirical research than to theory? Can he/she privilege the book instead of the article? Can he/she spread the bibliography listed in the end of the book along the text in order to soften the formality? Is there any breach for the formal daring in the rigidity of the fields ruled by the academy? Which field is more open to some kind of experimentation: communications, history, languages? Or does none of them allow any kind of infraction of the regulation?

A less attentive reading may lead to imagine that this text reflects dissatisfaction with the rules required by the scientific discourse. It is, however, an analysis in movement about the conditions of possibilities for enlarging the boundaries of the fields concerning research resources and narrative devices. There was no intention of reaching susceptibilities of historians or hyperdimension the role of journalists. Neither is this an 
intention of reducing everything to fiction. If it were necessary to strangely conclude using a question as synthesis, it would be: does the narrative in human sciences or applied social sciences have space for creative writing beyond the literary scope?

It is not difficult to figure out the disruption this proposition is able to cause. The standard answer certainly is: science is science and has its protocols of research and results dissemination. The characteristic of science, according to this specific perspective, would not be to do, but to think over doing. But how can one, echoing Morin's complexity, think over doing the act of doing, that is, the aspects involving the act of doing that thinks over another act of doing? The strategic sense of Pierre Bourdieu's reader recommends the evaluation of the analyst's force in his/her field. If he/she is dominated, it is better to follow the regulation. If he/she is dominant, there may be space for daring. But does not it affect his/her position? Does not it cause asphyxia according to Lyotard's warning?

Another aspect considered was the place of this question: political and administrative forums or academic texts? Sociology of science or epistemology? If each field has its regulations, what is the solution for making transdisciplinary rules, based on the idea of shared knowledge, without necessarily isolating oneself in a kind of slum controlled and enclosed to avoid infecting the others? Given the lack of a grand closing, this is suitable: is there space for narrative creativity in the dissemination of scientific results? "

Translation: Felícia Volkweis

\section{REFERENCES}

Bourdieu, P. (1998). On television. New York: The New Press.

Bourdieu, P. (1992). Les règles de l'art - genèse et structure du champ littéraire. Paris: Seuil.

Debord, G. (1995). The society of the spectacle. New York: Zone Books.

Feyerabend, P. (1993). Against method. New York: Verso.

Lyotard, J.-F. (1984). The postmodern condition: a report on knowledge. Manchester: Manchester University Press.

Morin, E. (1999). O método 3: o conhecimento do conhecimento. Porto Alegre: Sulina.

Silva, J. M. da. (2017). Diferença e descobrimento. O que é o imaginário. A hipótese do excedente de significação. Porto Alegre: Sulina.

Veyne, P. (1998). Writing history: essay on epistemology. Middletown: Wesleyan University Press.

\section{BIOGRAPHICAL NOTE}

Juremir Machado da Silva, Doctor of Sociology from Sorbonne, Paris V, writer, historian, journalist, radio broadcaster and translator, is researcher level $1 \mathrm{~B}$ of $\mathrm{CNPq}$, 
coordinator of the Postgraduate Program of the School of Communications of PUCRS, and author, among other books, of A miséria do jornalismo brasileiro (Petrópolis: Vozes, 2000), As tecnologias do imaginário (Porto Alegre: Sulina, 2003), O que pesquisar quer dizer (Porto Alegre: Sulina, 2010), História regional da infâmia: o destino dos negros farrapos $e$ outras iniquidades brasileiras, ou como se produzem os imaginários (Porto Alegre: L\&PM, 2010), Vozes da legalidade: política e imaginário na era do rádio (Porto Alegre: Sulina, 2011), Um escritor no fim do mundo: viagem com Michel Houellebecq à Patagônia (Rio de Janeiro: Record, 2011), Getúlio (Rio de Janeiro: Record, 2004), Solo (Rio de Janeiro: Record, 2008), 1930: águas da revolução (Rio de Janeiro: Record, 2010), A sociedade medíocre: passagem ao hiperespetacular (o fim do direito autoral, do livro e da escrita) (Porto Alegre, Sulina, 2012), Jango, a vida e a morte no exílio (Porto Alegre: L\&PM, 2013), 1964: golpe midiático-civil-militar (Porto Alegre: Sulina, 2014), Correio do Povo: a primeira semana de um jornal centenário (Porto Alegre: Sulina, 2015), Corruptos de estimação e outros textos sobre o golpe hiper-real (Porto Alegre: Sulina, 2016), Diferença e repetição: o que é o imaginário (Porto Alegre: Sulina, 2017), Raízes do conservadorismo brasileiro: a abolição na imprensa e no imaginário social (Rio de Janeiro: Civilização Brasileira, 2017).

ORCID: https://orcid.org/0000-0001-8105-5596

Email: Juremir@pucrs.br

Address: PUCRS, Av. Ipiranga, 6681 - Prédio 7 - Partenon - Porto Alegre/RS

CEP: $90619-900$

* Submitted: 03.05.2018

* Accepted: 12.07.2018 